\title{
CHARACTERIZATION OF CEMENT STABILIZED PAVEMENT LAYERS WITH ULTRASOUND TESTING
}

\author{
Ivana Barišić, Sanja Dimter, Tatjana Rukavina
}

Original scientific papers Performance of ultrasonic pulse velocity (UPV) in hydraulically bound mixtures is examined as a non-destructive testing, in order to estimate its potential for pavement material characterization. Test results show that an increase in cement content results in an increase in UPV values. Increase in steel slag aggregate content results in a decrease in UPV values. Analyses of relationship between UPV values and strengths have shown strong polynomial relationship. For UPV values ranging $2 \div 3,2 \mathrm{~km} / \mathrm{s}$ cement stabilized material can be classified as appropriate for usage in road construction. Test results have shown good potential for UPV measure as non-destructive method in cement stabilized material characterization.

Keywords: cement stabilized material; compressive strength; non-destructive testing; pavement; steel slag; ultrasound pulse velocity (UPV)

Karakterizacija cementom stabiliziranih nosivih slojeva kolničkih konstrukcija metodom ultrazvuka

Izvorni znanstveni članak

U radu je ispitana mogućnost primjena metode mjerenja brzine ultrazvučnog impulsa kao nerazorne metode pri karakterizaciji hidraulički vezanih materijala kolničkih konstrukcija. Rezultati ispitivanja su pokazali da povećanje količine cementa rezultira povećanjem vrijednosti brzine ultrazvuka. Povećanje udjela čeličanske zgure u agregatu rezultira smanjenjem vrijednosti brzine ultrazvuka. Analiza odnosa brzine ultrazvuka i čvrstoće materijala pokazala je jaku polinomnu vezu. Za vrijednosti brzine ultrazvuka u rasponu od $2 \div 3,2 \mathrm{~km} / \mathrm{s}$ cementom stabilizirani materijal može biti klasificiran kao prikladan za uporabu u cestogradnji. Rezultati ispitivanja pokazali su moguću uporabu metode mjerenja ultrazvuka kao nerazorne metode pri karakterizaciji cementom stabiliziranih materijala kolničke konstrukcije.

Ključne riječi: brzina ultrazvuka; cementom stabilizirani nosivi slojevi; čeličanska zgura; kolnička konstrukcija; nerazorno ispitivanje; tlačna čvrstoća

\section{Introduction}

Cement stabilized materials (or controlled low strength concrete) are coarse-grained soils and aggregate bound together by a stabilizing agent to produce hard, rigid mass. This material has variety of possible usages such as in backfills, structural fills, pavement bases, conduit beddings and void fillings [1]. The strength of this material varies depending on its application. It ranges from 2,1 MPa for construction of backfills with possible future excavation to $6,5 \mathrm{MPa}$ for construction of road base layers.

Construction of pavement containing stabilized base course is represented in both asphalt and concrete pavement structures. In asphalt pavement they are an important element in terms of capacity while in concrete pavements they prevent the emergence of material "pumping". Pavements containing stabilized base courses have the advantage of continuous increase of strength during time. In that way pavement can accommodate an increase in volume and axel weight of traffic over design period.

Cement stabilized mixes for usages in road construction are usually characterized by their compressive strength measured for 7 and 28 day curing period. This is time consuming method and requires testing on certain number of samples. On the other hand, utilization of non-destructive testing (NDT) in evaluation of material properties, particularly concrete is widely used in civil engineering.

Ultrasonic pulse velocity (UPV) is used as an indicator of the concrete strength with $95 \%$ confidence limits of about $\pm 20 \%$ on predicted strength [2]. It can be very effective and reliable in determining the concrete strength at early age (low strength) which creates opportunity for testing its reliability in characterization of cement stabilized materials used in road construction.

Application of UPV measurement in concrete characterization has been investigated by many researchers. Abo-Qudais [3] evaluates the effect of concrete aggregate gradation, water-cement ratio, and curing time on measured ultrasonic wave velocity. The results indicated that water-cement ratio and aggregate gradation have a significant effect on UPV. The UPV was found to decrease with the increase of water cement ratio and increase with the increase in aggregate size. In the research [4], the ultrasonic wave reflection method was applied for describing the initial setting of concrete. Ultrasonic wave reflection used in [4] is a one-sided approach that measures the mismatch coefficient of the mechanical impedances between a buffer (reference) material and a sample. This research can be incentive for UPV field application on pavement layers since the shear wave in the ultrasonic wave reflection technique does not need to be propagated through the thickness (it is a oneside approach). Aggelis et al. [5] conducted a study dealing with the characterization of non-visible subsurface damage in concrete. It is concluded that by scanning a surface with simple acoustic one-sided measurements, the identification of the location of the subsurface damage is possible, while the propagating wave gives information about the depth of the crack. This can be also beneficial in potential UPV application in field testing of pavement layers. Bohdan and Tomasz [6] analysed the ultrasound test methodology for determination of conversion factor for strength determined on various dimension samples. They gave formulas which allow to convert the strength from sample of any diameter to the different one. Zhu et al. [7] investigated air void effects on ultrasonic wave 
propagation in fresh cement pastes. Results of this study show the potential of using shear waves to monitor setting and hardening process of cement. Results of this study potentially can be beneficial in pavement construction, when making decision on allowing construction site traffic upon freshly built pavement layer. Trtnik and Turk [8] investigated possibility of using an ultrasonic wave transmission method to study the influence of superplasticizers on the formation of structure of cement pastes at early ages. So ultrasonic wave transmission method can be used in evaluation of new material influence on cement based materials properties.

Application of UPV method in the field of pavement materials characterization also has a long tradition. Thus, in year 1991, Sztukiewicz [9] publishes paper on the possibilities of applying ultrasonic methods in asphalt concrete testing concluding that this method can be useful in highway sufficiency rating. Tagdemir et al. [10] investigate possibilities of applying ultrasonic methods in asphalt concrete specimen testing in order to estimate its fatigue life. Results of this study indicated that only by examining the ultrasonic method it will be possible to predict the fatigue lives of the asphalt concrete specimens non-destructively, creating possibility of method application also in other pavement materials. The UPV method was also adopted to assess the dampening properties of pavement materials in [11]. Correlations between predicted values using mathematical model to calculate the acoustic absorption (impedance) of pavement materials and laboratory measured ultrasonic pulse time was excellent. The ultrasonic pulse time results were used to calculate the effective flow resistivity, which is the direct main input into the Traffic Noise Model developed by the Federal Highway Administration (FHWA) of the United States. Correlations between tire/pavement noise levels and laboratory calculated effective flow resistivity for each of the field mixtures were excellent. As for concrete, UPV is also used to determine dynamic modulus of asphalt mixtures [12]. Dynamic moduli obtained by ultrasonic transmission were compared with values directly determined by standard dynamic tests. Results indicated that dynamic moduli obtained by ultrasonic transmission can be used as a reference value for dynamic modulus of asphalt pavements at low strain, being necessary to apply a correction factor to replace the low frequency standard dynamic test, which is more expensive, difficult and time consuming. Dimter et al. [13] used an ultrasonic method to evaluate properties of a mixture of cement, fly ash and sand and concluded that ultrasonic velocity is an important indicator of density and compressive strength also of the quality of the stabilized mix.

Some of the latest researches on UPV measurement usually combine a few non-destructive methods. Thus, in [14] the internal-frost damage in cementitious material samples was investigated using the scanning electron microscope (SEM) imaging analysis, micro damage modelling and ultrasonic wave scattering techniques. In this study, ultrasonic wave scattering technique was developed for rapid measurement of the pore size distribution and volume fraction of the air in cementitious concrete, which provided important inputs to simplify the computational model for materials damages simulations.
In here presented study, correlation between results of NDT method and classical compressive strength method was done in order to define easier and faster way for cement stabilized layer characterization.

This article reports practical experience in the application of NDT method in road construction material characterization. In this study, steel slag from Croatian landfill is used as an alternative aggregate in cement stabilized material for usage as pavement base layer. The aim of this study was to identify possible application of NDT method in characterization of cement stabilized base course with the aim to define how the material strength can be estimated from ultrasound pulse velocity. For this purpose, the basic engineering properties (compressive and tensile strength) which are used for the characterization of these materials were determined. Laboratory testing was conducted on fifteen different mixtures. In mix design, three different amounts of binder ( $2 \%, 4 \%$ and $6 \%$ ) and two types of aggregate (steel slag and gravel) were used.

\section{Experimental program \\ 2.1 Material characterization}

As a natural material commonly used in road construction, gravel from the river Drava was used. This is local material, grey-brown colour, with a grain size $D_{50}$ $=6 \mathrm{~mm}$ and a degree of non-uniformity $U=d_{60} / d_{10}=20$. The maximum dry density and optimum water content defined by modified Proctor test according to the EN 13286-2: Unbound and hydraulically bound mixtures Part 2: Test methods for laboratory reference density and water content - Proctor compaction for used gravel were $2,06 \mathrm{~g} / \mathrm{cm}^{3}$ and $4,71 \%$ respectively.

Currently, there are two steel slag landfills in the Republic of Croatia and it is a combination of blastfurnace and electric arc furnace steel slag. The estimated quantities of steel slag on Croatian landfills are approximately 1,5 million tons. Slag from landfills in Croatia has high hardness which creates high milling costs. This results in higher costs of production of cement, if it is used as an additive to cement [15] and provides an opportunity for cost-effective approaches to the use of slag as aggregates in the supporting layers of pavement structures.

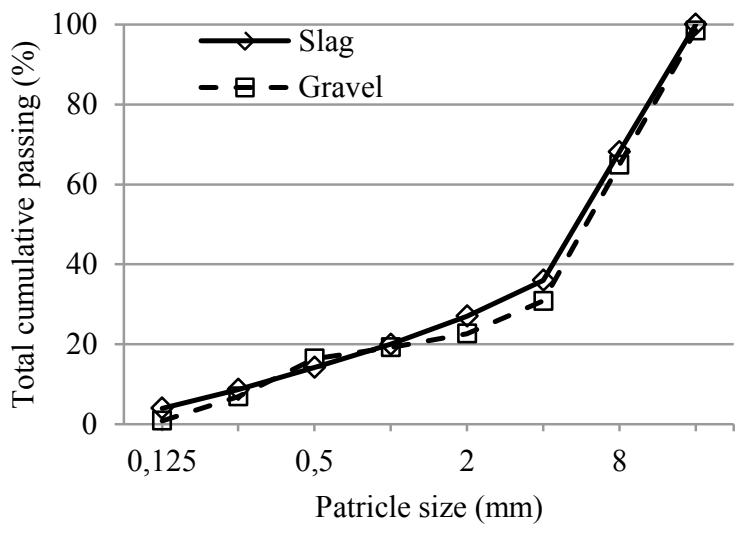

Figure 1 Particle size distribution curves for slag and gravel

Steel slag from the landfill near the town of Sisak was used as substitute aggregate material. Slag disposed in 
landfill near the Sisak plant has mixed composition, combination of blast furnace and electric furnace slag. A degree of non-uniformity of this material was $U=d_{60} / d_{10}$ $=21,4$ and a grain size $D_{50}=5,5 \mathrm{~mm}$. Chemical composition of slag used in this research is presented in
Tab. 1. Particle size distribution curves for both aggregates are shown in Fig. 1. As a binder, Portland cement of grade 32,5 (CEM II B/M (P-S) 32,5R) was used as $2 \%, 4 \%$ and $6 \%$ of aggregate mass.

Table 1 Chemical composition of steel slag

\begin{tabular}{|l|cccccccccc|}
\hline Chemical compound & $\mathrm{CaO}$ & $\mathrm{Fe}_{2} \mathrm{O}_{3}$ & $\mathrm{SiO}_{2}$ & $\mathrm{Al}_{2} \mathrm{O}_{3}$ & $\mathrm{MgO}$ & $\mathrm{MnO}$ & $\mathrm{SO}_{3}{ }^{2}$ & $\mathrm{~S}_{2}$ & $\mathrm{Na}_{2} \mathrm{O}$ & $\mathrm{K}_{2} \mathrm{O}$ \\
\hline Content (mass \%) & 24,98 & 25,45 & 17,08 & 5,40 & 10,58 & 8,91 & 0,25 & 0,05 & 0,12 & 0,13 \\
\hline
\end{tabular}

\subsection{Mix details and experimental method}

Table 2 Details of mixes compositions used in experimental program

\begin{tabular}{|c|c|c|c|}
\hline Mix. no & Cement (\%) & Gravel (\%) & Slag (\%) \\
\hline 1 & \multirow{5}{*}{2} & 100 & 0 \\
\hline 2 & & 75 & 25 \\
\hline 3 & & 50 & 50 \\
\hline 4 & & 20 & 75 \\
\hline 5 & & 0 & 100 \\
\hline 6 & \multirow{5}{*}{4} & 100 & 0 \\
\hline 7 & & 75 & 25 \\
\hline 8 & & 50 & 50 \\
\hline 9 & & 20 & 75 \\
\hline 10 & & 0 & 100 \\
\hline 11 & \multirow{5}{*}{6} & 100 & 0 \\
\hline 12 & & 75 & 25 \\
\hline 13 & & 50 & 50 \\
\hline 14 & & 20 & 75 \\
\hline 15 & & 0 & 100 \\
\hline
\end{tabular}

For determination of compressive and indirect tensile strength so as for ultrasound pulse velocity measurement, fifteen different cement stabilized mixtures were evaluated. Tab. 2 gives the details of mixes content that were used in the experimental program.

The specimens were prepared at their respective optimal moisture content and maximum dry density according to EN 13286-50: Unbound and hydraulically bound mixtures - Part 50: Method for the manufacture of test specimens of hydraulically bound mixtures using Proctor equipment or vibrating table compaction. The compacted specimens were $100 \mathrm{~mm}$ in diameter and 200 $\mathrm{mm}$ height. Prepared specimens were cured for 7, 28 and 90 days in a temperature and moisture controlled chamber $\left(20{ }^{\circ} \mathrm{C}\right.$ and $60 \%$ relative humidity). For every mixture and curing period, 6 of the kind specimens were prepared, 3 for each strength test.

Ultrasound pulse velocity measurement is one of the standard tests for concrete properties determination and it is defined by standard EN 12504-4: Testing concrete Part 4: Determination of ultrasonic pulse velocity. Pulse generator generates electrical impulses of a specific frequency and through the transmitter they are converted into mechanical energy which is submitted to a sample. The receiver on the other side of the specimen received turns mechanical energy into electrical energy of the same frequency. The time of passage of ultrasound through the specimen (length L of the specimen must be accurately measured) is measured electronically and is registered in the oscilloscope (T).

In addition to determining the dynamic modulus of elasticity, ultrasound pulse velocity is associated with the compressive strength. This relatively simple test is commonly applied in assessing the performance of hardened concrete $[2,16 \div 19]$. Cement stabilized material has similar composition to regular concrete and it is also known as controlled low strength material or lean concrete. Therefore, in this research was decided to define the properties of cement stabilized mixes by this method, although it is non-standard testing in road construction. UPV measurement is not affected by curing condition [2] which makes it particularly suitable for in situ characterization of road construction materials. Curing condition of imbedded materials in pavement layer depends on weather conditions.

In concrete mix, the main influence on UPV measurement is that of aggregate type, percentage and maximum size and cement percentage [20] so in this study two aggregate types and 3 cement percentages were used.

For cement stabilized materials, impulses in a frequency range of $20 \div 250 \mathrm{kHz}$ can be used [20] while ultrasonic pulses in the range of $40 \div 80 \mathrm{kHz}$ are suitable for the evaluation of concrete properties [16]. Size of transducer also influences the results of measurement. Velocity determined by the larger size transducer $(5 \mathrm{~cm}$ diameter) is higher than those determined by the small size transducer $(0,7 \mathrm{~cm}$ diameter $)$ [17]. So, for a better precision and a less disturbance of measurement, transducer of $5 \mathrm{~cm}$ diameter and frequency of $45 \mathrm{kHz}$ was used in this study. The impact of changes in the composition of hydraulically bound mixtures with fly ash and in the regime of care to the ultrasonic velocity is also presented in [13].

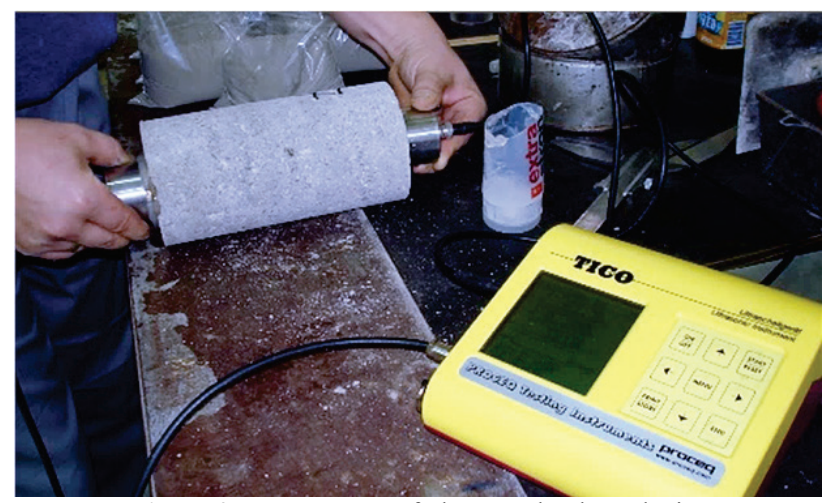

Figure 2 Measurement of ultrasound pulse velocity

UPV technique is based on the measurement of wave velocities through material. For every sample, measurement of transmission time was recorded and pulse transmission velocity was calculated using Eq. (1):

$v=\frac{L}{T}$, 
where $v$ is transmission velocity $(\mathrm{m} / \mathrm{s}), L$ is transmission distance equal to sample length $(\mathrm{m})$ and $T$ is measured transmission time (s). Ultrasound pulse velocity is determined as average of three measurements for every sample. In Fig. 2, measurement of UPV is presented.

After conducted non-destructive tests, the compressive and indirect tensile strength were determined. Compressive strength was determined in accordance with standard EN 13286-41: Unbound and hydraulically bound mixtures - Part 41: Test method for determination of the compressive strength of hydraulically bound mixtures, as an average stress in the specimen exposed to uniaxial pressure due to the force causing the stress fracture. Compressive strength testing is

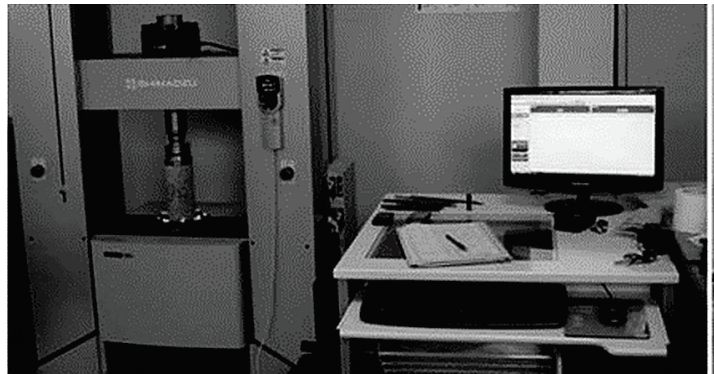

a) shown in Fig. 3a. Tensile strength in this study was determined by the indirect test method according to standard EN 13286-42: Unbound and hydraulically bound mixtures - Part 42: Test method for the determination of the indirect tensile strength of hydraulically bound mixtures. This method is considered the most appropriate for practical testing of cement stabilized materials since the equipment is the same or very similar to the equipment for compressive strength testing. In this method, loading is applied on a cylindrical specimen via loading bar as shown in Fig. 3b. Such load causes relatively uniform strain perpendicular to the diameter plane at which the pressure is applied.
Figure 3 Strength test procedure: a) compression and b) indirect tension

\section{Results and discussion}

In this section regarding experimental results, some diagrams and tables are presented in order to show the relationship between the most effective parameters on UPV as discussed earlier in the text. Analyses of

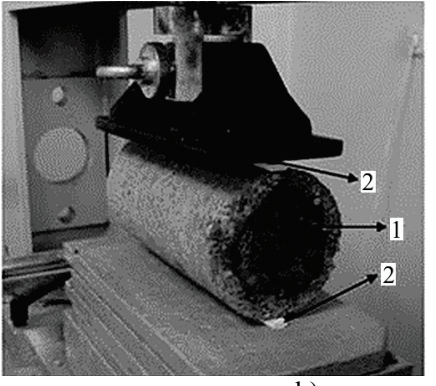

1 - specimen

2 - loading bar

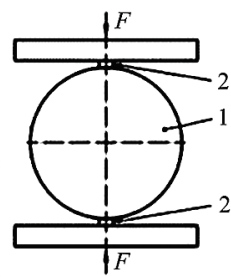

correlation between strengths and UPV was done in order to define parameters for characterization of materials used in road construction by NDT. Results of UPV, compressive and indirect tensile strength for 7, 28 and 90 curing days are shown in Tab. 3.

Table 3 Results of 7, 28 and 90 days UPV $(V$ in $\mathrm{km} / \mathrm{s})$, compressive strength $\left(F_{\mathrm{c}}\right.$ in $\left.\mathrm{MPa}\right)$ and indirect tensile strength $\left(F_{\mathrm{t}}\right.$ in $\left.\mathrm{MPa}\right)$ tests

\begin{tabular}{|cccccccccccccccccc}
\hline Mix. no & 1 & 2 & 3 & 4 & 5 & 6 & 7 & 8 & 9 & 10 & 11 & 12 \\
\hline$V_{7}$ & 1,78 & 2,00 & 2,18 & 2,06 & 1,36 & 3,03 & 2,53 & 2,64 & 2,70 & 2,29 & 3,35 & 3,25 & 2,75 & 2,74 & 2,77 \\
$V_{28}$ & 1,35 & 2,18 & 2,49 & 2,37 & 1,54 & 2,29 & 3,12 & 3,06 & 3,03 & 2,83 & 3,25 & 3,49 & 3,20 & 3,30 & 3,21 \\
$V_{90}$ & 2,57 & 2,73 & 2,71 & 2,39 & 2,00 & 3,35 & 3,23 & 3,25 & 3,14 & 2,67 & 3,60 & 3,70 & 3,32 & 3,42 & 2,95 \\
\hline$F_{\mathrm{c}, 7}$ & 0,82 & 0,69 & 1,10 & 1,43 & 1,24 & 2,94 & 2,22 & 1,83 & 2,05 & 3,13 & 3,93 & 5,08 & 2,65 & 2,91 & 4,18 \\
$F_{\mathrm{c}, 28}$ & 1,07 & 1,89 & 2,17 & 2,60 & 1,76 & 3,31 & 5,33 & 3,68 & 4,91 & 3,64 & 9,67 & 9,10 & 6,17 & 7,40 & 8,04 \\
$F_{\mathrm{c}, 90}$ & 1,97 & 2,63 & 2,95 & 3,13 & 2,93 & 6,47 & 6,43 & 5,85 & 5,96 & 5,88 & 8,62 & 10,19 & 8,94 & 8,39 & 6,18 \\
\hline$F_{\mathrm{t}, 7}$ & 0,06 & 0,10 & 0,12 & 0,12 & 0,11 & 0,36 & 0,21 & 0,37 & 0,32 & 0,19 & 0,75 & 0,79 & 0,52 & 0,39 & 0,43 \\
$F_{\mathrm{t}, 28}$ & 0,16 & 0,24 & 0,28 & 0,31 & 0,24 & 0,61 & 0,63 & 0,66 & 0,72 & 0,71 & 1,52 & 1,25 & 1,00 & 1,19 & 1,35 \\
$F_{\mathrm{t}, 90}$ & 0,30 & 0,32 & 0,35 & 0,33 & 0,29 & 1,15 & 1,34 & 0,75 & 0,99 & 0,69 & 1,46 & 1,88 & 0,88 & 1,26 & 0,94 \\
\hline
\end{tabular}

\subsection{Influence of cement content on ultrasound pulse velocity}

Influence of cement content on UPV can be seen in Fig. 4. Increase in cement content results in UPV increase. This result only verifies previous research results $[20,21]$ in which increase in cement content causes an increase in compressive strength and consequently an increase in UPV. Increase in cement content from $2 \%$ to $4 \%$ seems to be more effective on UPV values then increase from $4 \%$ to $6 \%$ cement content. Average increase in UPV values for cement content increase from $2 \%$ to $4 \%$ is $0,765 \mathrm{~km} / \mathrm{s}$ while for increase in cement content from $4 \%$ to $6 \%$ it is 0,342 $\mathrm{km} / \mathrm{s}$.

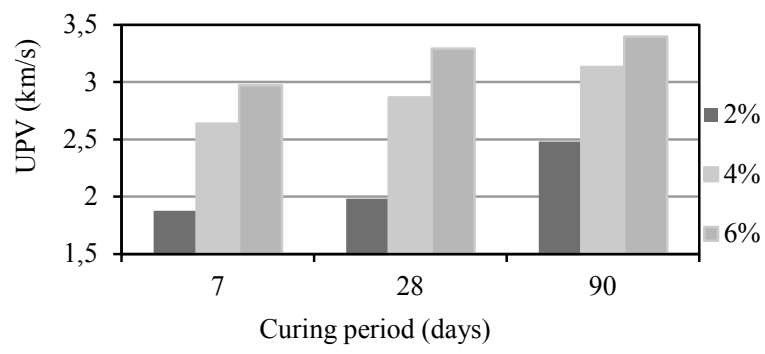

Figure 4 Influence of cement content on ultrasound pulse velocity

\subsection{Influence of aggregate type on ultrasound pulse velocity}

UPV of cement stabilized steel slag mixtures for 7, 28 and 90 days curing age is summarized in Fig. 5a to $5 \mathrm{c}$, respectively. For mixtures with $2 \%$ cement content is observed increase in UPV with increase in slag content up 
to $75 \%$ for all curing ages. On the other hand, it is observed a decreasing trend in the UPV values with an increase of slag content for mixtures with $4 \%$ and $6 \%$ cement content.

A high impact is generally observed of the amount of a binder on variation in UPV for mixtures containing slag. Filling of slag grain surface voids with cement pastes causes change in density and condition for transition of pulses. As it is known from earlier researches [16, 17, 20, 21], there is significant influence of porosity, cement paste content and compressive strength on UPV. The influence of steel slag aggregate on strength of the mixtures is presented in more detail in [22]

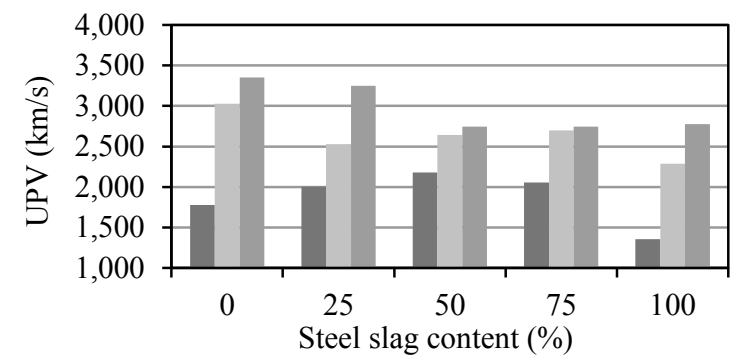

a)

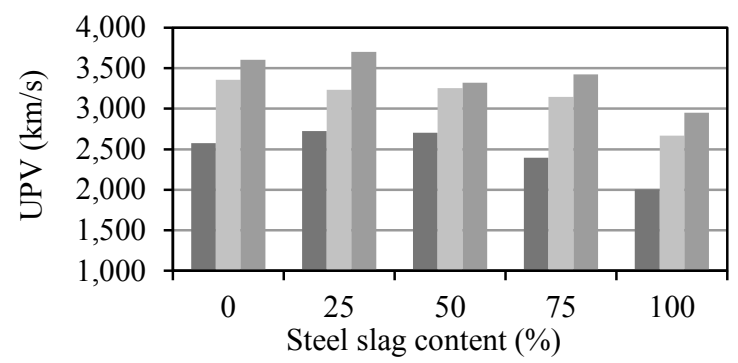

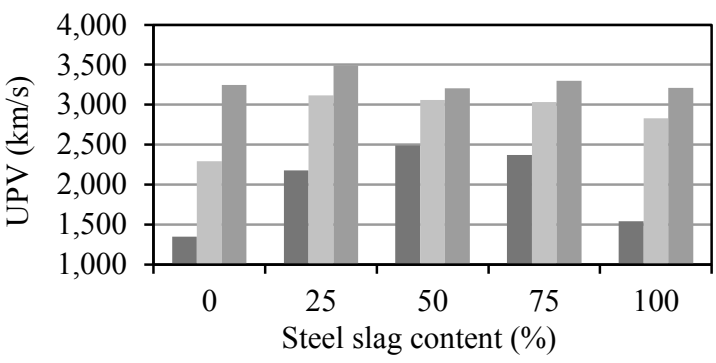

b)

$-2 \%$ cement $\quad 4 \%$ cement $\quad 6 \%$ cement

Figure 5 Influence of aggregate type on ultrasound pulse velocity for a) 7; b) 28 and c) 90 days curing period

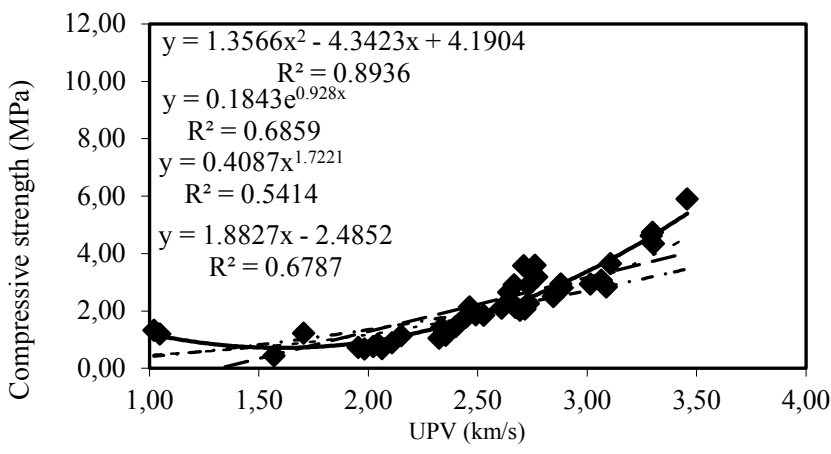

a)

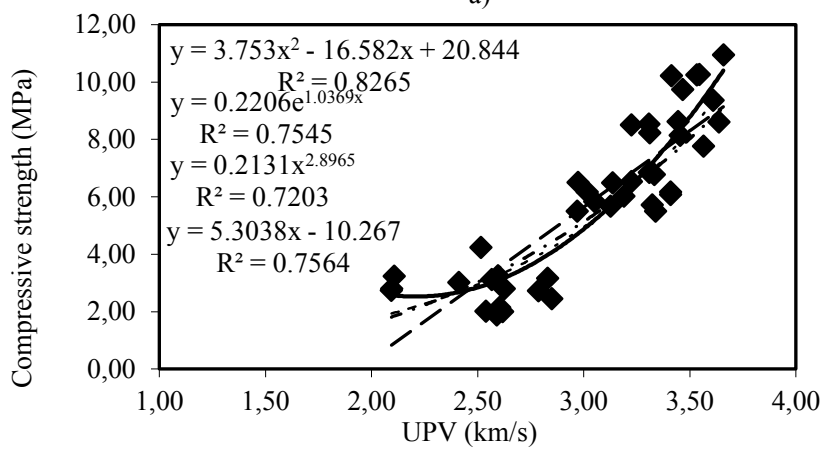

c)

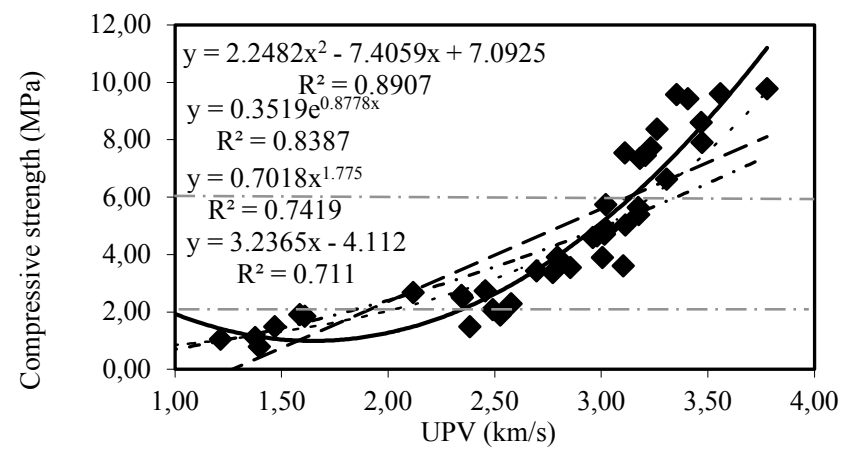

b)

$$
\text { - - - - Power } \quad \text { - - - Linear }
$$

Figure 6 Relation between pulse velocity and compressive strength for a) 7; b) 28 and c) 90 days curing period

\subsection{The relationship between ultrasonic pulse velocity and strength of cement stabilized material}

Many authors have studied correlation between UPV and compressive strength. Popularity of this study lies in need for fast determination of material characteristic and easy and fast conduction of UPV measurement. There are many expressions given by different authors for correlation of UPV and compressive strength and some of them are summarized in work by Breysse [20]. Basically, there are three models commonly used for concrete structures: exponential law, power law and linear law. Since cement stabilized material is similar to concrete by its composition and behaviour, these laws were also used in this study. Results of correlation investigation between UPV and compressive and indirect tensile strength for 
cement stabilized material are presented in Fig. 6 and Fig.

7 respectively.

Analyses have shown that the correlation between compressive strength and UPV, as well as the correlation between indirect tensile strength and UPV is best presented by polynomial law even though this model is not usually analysed for concrete structures. This correlation is expressed by Eq. (2):

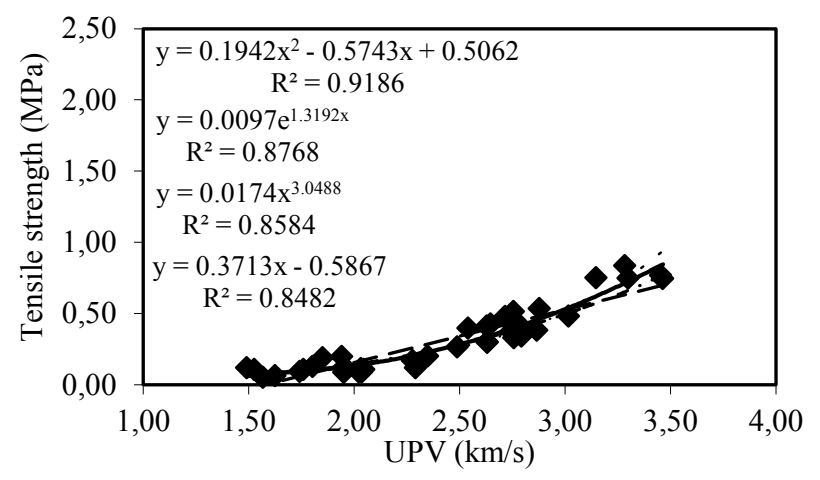

a)

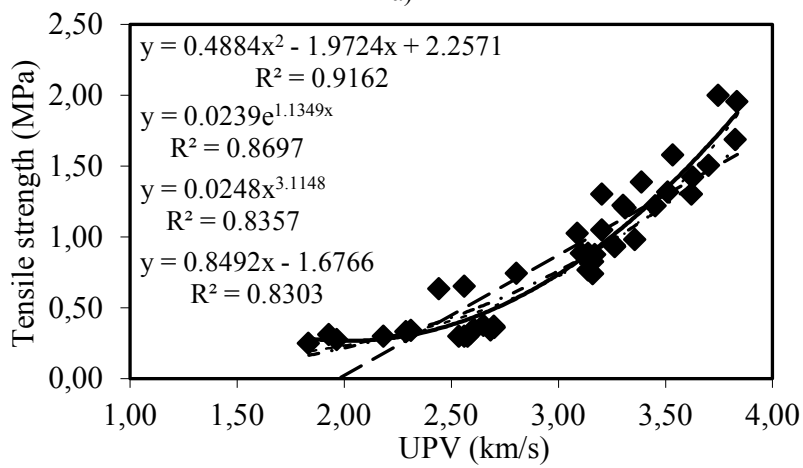

c)
$F=A v^{2}-B v+C$,

where $F$ is the strength (compressive or indirect tensile) in $\mathrm{MPa}, v$ is the pulse velocity in $\mathrm{km} / \mathrm{s}$ and $A, B$ and $C$ are empirical constants.

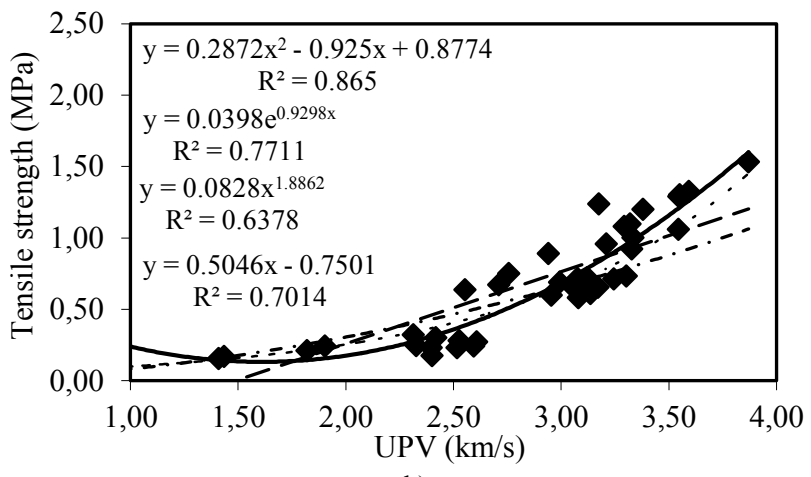

b)

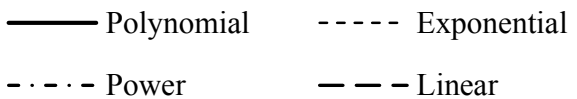

Figure 7 Relation between pulse velocity and indirect tensile strength for a) 7; b) 28 and c) 90 days curing period

Coefficient of determination $\left(R^{2}\right)$ by polynomial law is around 0,9 which presents very strong correlation between UPV and strength of cement stabilized material. Similar values are obtained for exponential law so it can be concluded that these two laws are most appropriate for strength prediction of cement stabilized material.

Classification of the quality of concrete on the basis of pulse velocity defines excellent quality concrete for UPV values higher than $4,5 \mathrm{~km} / \mathrm{s}$ [23]. Concrete for which measured UPV values are less than $2 \mathrm{~km} / \mathrm{s}$ is classified as very poor quality concrete. In standard EN 13791: Assessment of in-situ compressive strength in structures and precast concrete components, it is given relationship between in-situ compressive strength determined on cores taken from structure and UPV. Concretes having UPV less than $4,25 \mathrm{~km} / \mathrm{s}$ can be correlated with compressive strength less than $5 \mathrm{MPa}$.

The similar classification is given in this research. Classification of cement stabilized material for usage in pavement construction is defined by its 28 day compressive strength. Good quality cement stabilized material which can be used in pavement construction has 28 days compressive strength between 2 and $6 \mathrm{MPa}$. Lower values than $2 \mathrm{MPa}$ present too weak material which cannot endure traffic load. However, higher values of compressive strength present too rigid material which can cause reflective cracks on surface pavement layers. In
Fig. $5 \mathrm{~b}$ can be seen that for this range of compressive strength, characteristic UPV values can be determined. For UPV less than $2 \mathrm{~km} / \mathrm{s}$ and more than $3,2 \mathrm{~km} / \mathrm{s}$, cement stabilized material can be classified as inappropriate for road construction purposes since it has compressive strength less than $2 \mathrm{MPa}$ i.e. more than $6 \mathrm{MPa}$. For UPV values between 2 and $3,2 \mathrm{~km} / \mathrm{s}$, cement stabilized material can be classified as good quality material for road construction purposes.

\section{Conclusion}

Aiming to enhance possibilities of NTD method application in road construction, a survey was conducted on defining properties of hydraulically stabilized mixes with various composition. Analyses of UPV measurement and strength results of stabilized mixes lead to the following conclusions:

1. Increase in cement content results in an increase of UPV values.

2. There is high influence of aggregate type on UPV values depending on cement content. Mixes with $2 \%$ cement content show increase in UPV with the increase of the ratio steel slag/gravel. Mixes with higher cement content (4\% and $6 \%$ ) generally show decreasing trend in UPV with an increase in slag content. 
3. Analysing the relationship between UPV values and strengths (compressive and indirect tensile), strong polynomial relationship was observed for all curing ages. The general correlation coefficient for all mixes and curing ages was 0,87 for compressive strength and 0,90 for indirect tensile strength.

4. According to the European standard EN 14227-1, hydraulically bound mixes are classified according to 28 day compressive strengths. Correlation between 28 compressive strength and UPV is very strong, so this NDT method can be used in characterization of cement stabilized material.

5. For UPV values in range of $2 \div 3,2 \mathrm{~km} / \mathrm{s}$ cement stabilized material can be classified as appropriate for usage in road construction.

The results of this study represent significant stimulation for the possible use of non-destructive testing in the characterization of hydraulically bound mixes for pavement base layer, which have both technical and economic justification in road construction

\section{References}

[1] Achtemichuk, S.; Hubbard, J.; Sluce, R.; Shehata, M. H. The utilization of recycled concrete aggregate to produce controlled low-strength materials without using Portland cement. // Cement \& Concrete Composites. 31, (2009), pp. 564-569. DOI: 10.1016/j.cemconcomp.2008.12.011

[2] Hamid, R.; Yusof, K. M.; Zain, M. F. M. A combined ultrasound method applied to high performance concrete with silica fume. // Construction and Building Materials. 24(2010), pp. 94-98. DOI: 10.1016/j.conbuildmat.2009.08.012

[3] Abo-Qudais, S. A. Effect of concrete mixing parameters on propagation of ultrasonic waves. // Construction and Building Materials. 19, 4(2005), pp. 257-263. DOI: 10.1016/j.conbuildmat.2004.07.022

[4] Yim, H. J.; Kim, J. H.; Shah, S. P. Ultrasonic monitoring of the setting of cement-based materials: Frequency dependence. // Construction and Building Materials. 65(2014), pp. 518-525. DOl: 10.1016/j.conbuildmat.2014.04.128

[5] Aggelis, D. G.; Leonidou, E.; Matikas, T. E. Subsurface crack determination by one-sided ultrasonic measurements. // Cement \& Concrete Composites. 34(2012), pp. 140-146. DOI: 10.1016/j.cemconcomp.2011.09.017

[6] Bohdan, S.; Tomasz, K. Determination of the Influence of Cylindrical Samples Dimensions on the Evaluation of Concrete and Wall Mortar Strength Using Ultrasound Method. // Procedia Engineering. 57(2013), pp. 1078-1085. DOI: 10.1016/j.proeng.2013.04.136

[7] Zhu, J.; Kee, S.-H.; Han, D.; Tsai, Y. T. Effects of air voids on ultrasonic wave propagation in early age cement pastes. // Cement and Concrete Research. 41(2011), pp. 872-881. DOI: 10.1016/j.cemconres.2011.04.005

[8] Trtnik, G.; Turk, G. Influence of superplasticizers on the evolution of ultrasonic P-wave velocity through cement pastes at early age. // Cement and Concrete Research. 51(2013), pp. 22-31. DOI: 10.1016/j.cemconres.2013.04.007

[9] Sztukiewicz, R. J. Application of ultrasonic methods in asphalt concrete testing. // Ultrasonics. 29, 1(1991), pp. 512. DOI: 10.1016/0041-624X(91)90167-7

[10] Tigdemir, M.; Kalyoncuoglu, S. F.; Kalyoncuoglu, U. Y. Application of ultrasonic method in asphalt concrete testing for fatigue life estimation. // NDT \& E International. 37(2004), pp. 597-602. DOI: 10.1016/j.ndteint.2004.03.006

[11] Biligiri, K. P.; Kaloush, K. E. Prediction of Pavement Materials' Impedance Using Ultrasonic Pulse Velocity. //
Road Materials and Pavement Design. 10, 4(2009), pp. 767-787. DOI: $10.1080 / 14680629.2009 .9690226$

[12] Norambuena-Contreras, J.; Castro-Fresno, D.; VegaZamanillo, A.; Celaya, M.; Lombillo-Vozmediano, I. Dynamic modulus of asphalt mixture by ultrasonic direct test. // NDT\&E International. 43(2010), pp. 629-634. DOI: 10.1016/j.ndteint.2010.06.007

[13] Dimter, S.; Rukavina, T.; Barišić, I. Application of the ultrasonic method in evaluation of properties of stabilized mixtures. // The Baltic Journal of road and bridge engineering. $6, \quad 3(2011), \quad$ pp. 177-184. DOl: 10.3846/bjrbe.2011.23

[14] Ng, K.; Sun, Y.; Dai, Q.; Yu, X. Investigation of internal frost damage in cementitious materials with micromechanics analysis, SEM imaging and ultrasonic wave scattering techniques. // Construction and Building Materials. 50(2014), pp. 478-485. DOI: 10.1016/j.conbuildmat.2013.09.061

[15] Netinger, I.; Jelčić Rukavina, M.; Bjegović, D. Possibility of using domestic slag as concrete aggregate. // Građevinar. 62, 1(2010.), pp. 35-43.

[16] Nik, A. S.; Omran, O. L. Estimation of compressive strength of self-compacted concrete with fibers consisting nano-SiO2 using ultrasonic pulse velocity. // Construction and Building Materials. 44(2013), pp. 654-662. DOI: 10.1016/j.conbuildmat.2013.03.082

[17] Benouis, A.; Grini, A. Estimation of concrete's porosity by ultrasounds. // Physics Procedia, 21(2011), pp. 53-58. DOI: 10.1016/j.phpro.2011.10.009

[18] del Río, L. M.; Jiménez, A.; López, F.; Rosa, F. J.; Rufo, M. M.; Paniagua, J. M. Characterization and hardening of concrete with ultrasonic testing. // Ultrasonics. 42(2004), pp. 527-530. DOI: 10.1016/j.ultras.2004.01.053

[19] Panesar, D. K.; Shindman, B. Elastic properties of selfconsolidating concrete. // Construction and Building Materials. 25 (2011), pp. 3334-3344. DOI: 10.1016/j.conbuildmat.2011.03.024

[20] Breysse, D. Nondestructive evaluation of concrete strength: An historical review and a new perspective by combining NDT methods. // Construction and Building Materials, 33(2012), pp. 139-163. DOI: 10.1016/j.conbuildmat.2011.12.103

[21] Hamidian, M.; Shariati, M.; Arabnejad, M. M. K.; Sinaei, $\mathrm{H}$. Assessment of high strength and light weight aggregate concrete properties using ultrasonic pulse velocity technique. // International Journal of the Physical Sciences. 6, 22(2011), pp. 5261-5266.

[22] Barišić, I.; Dimter, S.; Rukavina, T. Strength properties of steel slag stabilized mixes. // Composites: Part B. 58(2014), pp. 386-391. DOI: 10.1016/j.compositesb.2013.11.002

[23] Guidebook on non-destructive testing of concrete structures. 2002, Vienna: International Atomic Energy Agency.

\section{Authors' addresses}

Ivana Barišić, PhD, Assistant Professor

University of Osijek, Faculty of Civil Engineering Osijek Drinska 16a, 31000 Osijek, Croatia E-mail: ivana@gfos.hr

\section{Sanja Dimter, PhD, Associate Professor}

University of Osijek, Faculty of Civil Engineering Osijek Drinska 16a, 31000 Osijek, Croatia E-mail: sdimter@gfos.hr

\section{Tatjana Rukavina, PhD, Full Professor}

Faculty of Civil Engineering, University of Zagreb Fra Andrije Kačića-Miošića 26, 10000 Zagreb, Croatia E-mail: rukavina@grad.h 